\title{
'TO BE, OR NOT TO BE, A ChARITY?' THAT IS THE QUESTION FOR PRESCRIBED BODIES CoRPORATE UNDER THE NATIVE TITLE ACT
}

\section{Dr Fiona MARTIN}

\begin{abstract}
This article evaluates the taxation concessions and other advantages that flow from being a charity and how these might apply to native title groups under the Native Title Act 1993 (Cth). Specifically, it examines the role of the Prescribed Body Corporate (' $P B C$ ') under the Native Title Act and the potential for, and limitations of, these bodies carrying on business, engaging in community development and accumulating funds whilst also having charitable status. The article examines the financial size and geographical status of current PBCs that have been identified as not being charities and analyses the potential benefits for these organisations if they become charities. It concludes with an evaluation of the disadvantages and disadvantages that charitable status would bring to these PBCs.
\end{abstract}

\section{INTRODUCTION}

The legal status 'charity' has been in existence for several hundred years, ${ }^{1}$ and carries with it a significant number of tax concessions including the exemption from income $\operatorname{tax}^{2}$ It also imposes certain legal requirements and obligations. The attraction of the income tax exemption has led to the widespread establishment of charities by Indigenous Australians who are in receipt of mining payments. ${ }^{3}$ In particular, studies by the Australian Institute of Aboriginal and Torres Strait Islander Studies ('AIATSIS'), a research institute funded by the Commonwealth Government, ${ }^{4}$

\footnotetext{
* Associate Professor, Taxation and Business Law, Australia Business School, University of New South Wales. The article's title was taken from Native Title Research Unit, 'Role of the ACNC in the Native Title Space', Newsletter, August 2014, 9.

${ }^{1}$ Gino Dal Pont, Law of Charity (LexisNexis Butterworths, 2010); Kerry O'Halloran, Charity Law and Social Inclusion (Routledge, 2006).

${ }^{2}$ Income Tax Assessment Act 1997 (Cth) ('ITAA97') ss 50-1, 50-5.

${ }^{3}$ Minerals Council of Australia ('MCA') and National Native Title Council ('NNTC'), Submission to Treasury, Consultation Paper: Native Title, Indigenous Economic Development and Tax, 30 November 2010, 11. The MCA represents Australian mining companies that are responsible for $85 \%$ of mining in Australia.

${ }^{4}$ AIATSIS is a Commonwealth statutory authority within the Department of Industry, Innovation, Science, Research and Tertiary Education portfolio. It is the national research and collecting institution for information and research about the cultures and societies of
} 
confirm that many 'native title groups" ${ }^{5}$ use a charitable entity to enter into resource agreements and/or receive mining payments. ${ }^{6}$

In order to gain charitable status at the federal government level, a charity must register with the Australian Charities and Not-for-profit Commission ('ACNC'). Research by the ACNC undertaken in 2013 reveals that, out of 118 corporations established to hold native title, referred to as prescribed bodies corporate ('PBCs'), ${ }^{8}$ only 23 were charities. ${ }^{9}$ This means that 95 PBCs were not charities.

The reluctance to register PBCs as charities is surprising given the range of taxation and legal benefits that charitable status offers. As already stated, all charities that are registered with the ACNC and endorsed by the Australian Taxation Office ('ATO') are exempt from income tax. This means that any income that they receive, either in the form of interest generated from investments or business income, is not subject to income tax. ${ }^{10}$ There are other benefits to PBCs organising themselves as charities, including the ability to exist in perpetuity, all revenue being reinvested into the charity's charitable purposes, and that charitable status is often the threshold criteria for gaining government grants. A further advantage from the mining industry perspective is that the use of charities demonstrates that the funds are 'doing a public good', which enhances their social responsibility and their reputation.

This article evaluates the advantages and disadvantages that flow from being a charity and how these might apply to the 95 PBCs that have not gained charitable status. The article first provides an overview of the law in Australian that defines a charity and discusses the benefits of PBCs obtaining charitable status as well as the challenges that PBCs face if they gain charitable status. The article then examines the financial

\footnotetext{
Aboriginal and Torres Strait Islander peoples, past and present

$<$ http://www.aiatsis.gov.au/corporate/about.html $>$.

${ }^{5}$ This term is used in this article to refer to a group of Indigenous Australians who are either in the pre-determinative phase of a native title claim or who have successfully made a claim for native title under the Native Title Act 1993 (Cth) ('NTA').

${ }^{6}$ Lisa Strelein and Tran Tran, 'Taxation of Trusts and the Distribution of Benefits under Native Title Agreements' (Native Title Research Report No 1, AIATSIS, 2007) [2.1]; Lisa Strelein, 'Taxation of Native Title Agreements' (Native Title Research Monograph No 1, AIATSIS, 2008) 31.

${ }^{7}$ The ACNC was established under the Australian Charities and Not-for-Profits Commission Act 2012 (Cth) to regulate and educate the charity and not-for-profit ('NFP') sector in Australia.

${ }^{8}$ Once the Federal Court makes a determination that native title exists under the NTA, the members of the native title group are required by the Act to establish a body corporate (the $\mathrm{PBC}$ ) to represent them as a group and manage their native title rights and interests; see NTA ss 55-57.

${ }^{9}$ Native Title Research Unit, Annie Keely, Victor Lovett and Caitlin Patterson, 'Role of the ACNC in the Native Title Space', Newsletter, August 2014, 6.

${ }^{10}$ ITAA97 Div 50.
} 
size and geographical status of current PBCs that are not charities and analyses the potential benefits for these organisations if they obtain charitable status.

\section{Benefits of Prescribed Bodies Corporate ESTABLISHING AS CHARITIES}

\section{A Charitable Status at Common Law and the Federal Income Tax Exemption}

A review of the literature strongly suggests that the main reason why an Indigenous group establishes itself as a charity is in order to gain the exemption from income tax. ${ }^{11}$ In order to understand why it is advantageous for PBCs to seek charitable status, it will be useful to give a brief overview of the legal requirements for being a charity in Australia and how these apply to PBCs.

Until 2014 there was no statutory definition of 'charity', and Australia followed the common law in order to determine whether or not an organisation was a charity. The common law states that a 'charity' must be not for profit or 'NFP'. ${ }^{12}$ In other words, it must be an organisation that does not distribute its surpluses to members. These requirements have been continued in section 5 of the Charities Act 2013 (Cth) ('Charities Act') which enacts a statutory definition of charity in Australia and which applies to all federal legislation. ${ }^{13}$

A NFP cannot distribute surpluses to its members and, on a winding up, must distribute any surplus to an organisation with similar objectives which is also NFP. A NFP can still make a profit or surplus, but this profit must be used to carry out its purposes and must not be distributed to owners, members or other private people. ${ }^{14}$ Section 5(a) of the Charities Act continues the NFP requirement for an entity to be a charity.

The English common law relating to charities commenced with the Preamble to the Charitable Uses Act 1601 (the Statute of Elizabeth). ${ }^{15}$ This statute, now repealed, set out a list of charitable purposes. The list was never meant to be exhaustive but has

\footnotetext{
${ }^{11}$ MCA and NNTC, above n 3, 11; Strelein and Tran, above n 6 [2.1]; Strelein, above n 6, 31.

${ }^{12}$ Re Smith's Wills Trusts; Barclays' Bank Ltd v Mercantile Bank Ltd [1962] 2 All ER 563; Ann O'Connell, 'The Tax Position of Charities in Australia - Why Does It Have to Be So Complicated?' (2008) 37 AT Rev 17, 24.

${ }^{13}$ It should be remembered that the common law still applies for state law purposes, so that when state legislation, such as local government rating Acts, refers to a charity it is referring to an entity that satisfies the common law definition.

${ }^{14}$ ATO, Getting Started for Non Profit Organisations $<$ https://www.ato.gov.au/Nonprofit/Getting-started-for-non-profit-organisations/Is-your-organisation-non-profit-/>.

${ }^{15}$ See Dal Pont, above n 1; O’Halloran, above n 1.
} 
been used as a reference list in accordance with the 'spirit or intendment' rule ${ }^{16}$ in the subsequent case law. Nearly 300 hundred years after the enactment of the Charitable Uses Act, Lord Macnaghten, in Commissioners for Special Purposes v Pemsel, ${ }^{17}$ stated that the legal meaning of 'charity' could be classified into four separate divisions. These are:

- The relief of poverty;

- The advancement of education;

- The advancement of religion; and

- Other purposes beneficial to the community. ${ }^{18}$

These divisions have been accepted in all common law countries, although there have been some modifications. Prior to 2013, the High Court of Australia confirmed that Australian law follows the four Pemsel heads of charity and the Preamble. ${ }^{19}$ This has been confirmed by the $\mathrm{ATO}^{20}$ and the statutory definition of charity in the Charities Act also specifically continues the common law charitable purposes. ${ }^{21}$

As well as having charitable purposes or objects the common law confirms that, for an organisation to be a charity, its purposes must be of benefit both to the public, ${ }^{22}$ and also to society. ${ }^{23}$

In order to have a 'charitable purpose', there must be some actual benefit resulting from the entity's objectives, although this extends beyond material benefit to other forms including social, mental and spiritual. ${ }^{24}$ The case law that considers this issue is usually centred on the question of whether or not the relevant purpose falls within the fourth Pemsel head, 'other purposes beneficial to the community'. For example, in The Incorporated Council of Law Reporting of the State of Queensland $v$ Commissioner of Taxation, ${ }^{25}$ the High Court of Australia held that the production of law reports was a matter that was beneficial to the community in a charitable sense.

\footnotetext{
${ }^{16}$ This rule provides that even though the purpose cannot be defined as coming under one of the other established heads of charity, it will nonetheless be construed as charitable if it can be interpreted as falling with the 'sprit or intendment' of the Preamble.

${ }^{17}$ [1891] AC 531.

${ }^{18}$ Ibid 583.

${ }^{19}$ Federal Commissioner of Taxation $v$ Word Investments Ltd [2008] HCA 55.

${ }^{20}$ ATO, Income Tax and Fringe Benefits Tax: Charities, TR 2011/4, 2011 [12].

${ }^{21}$ Charities Act s 12 which then applies item 7 of sch 2 to the Charities (Consequential Amendments and Transitional Provisions) Act 2013 (Cth).

${ }^{22}$ Royal National Agricultural and Industrial Association v Chester [1974] 3 ALR 486, 487.

${ }^{23}$ Oppenheim v Tobacco Securities Trust Co Ltd [1951] AC 297.

${ }^{24}$ Dal Pont, above n 1 [3.37].

${ }^{25}$ (1971) 125 CLR 659, 667-9.
} 
In addition to the above requirement, the courts have stated that, in order to be charitable, an organisation's purposes must benefit the community or a section of the community. Lord Simonds summarised this as:

\begin{abstract}
The question is whether that class of persons can be regarded as such a 'section of the community' as to satisfy the test of public benefit. These words 'section of the community' have no special sanctity, but they conveniently indicate ... that the quality which distinguishes them [the possible beneficiaries] from other members of the community, so that they form by themselves a section of it, must be a quality which does not depend on their relationship to a particular individual. It is for this reason that a trust for the education of members of a family or, as in In re Compton [1945] Ch 123, of a number of families cannot be regarded as charitable. ${ }^{26}$
\end{abstract}

Native title groups that establish their PBC as a charity often do so for the charitable purposes of relief of poverty. ${ }^{27}$ At common law, the charitable class of relief of poverty clearly covers relief of absolute destitution, although it is not confined to this. ${ }^{28}$ Some PBCs also include as one of their charitable purposes the fourth Pemsel category, 'other purposes beneficial to the community'. For a purpose to be charitable under this category at common law, it must not only be of benefit to the public or a significant section of it, but it must also be within the spirit and intendment of the Preamble to the Statute of Elizabeth. ${ }^{29}$ The categories of charitable objects that have been held to fall within this area are broad and include aid to Indigenous persons. ${ }^{30}$

\title{
B Statutory Definition of Charity for Federal Law Purposes
}

In recent years, several common law countries have established statutory or legislative definitions of charity. ${ }^{31}$ There are various policy and legal reasons for this. These reasons include the importance of recognition of charities and charitable purpose, which is aided by the enactment of a specific statute, assistance to the public in understanding the width of charitable purposes, and an attempt to reduce complexity by setting out a statutory list of charitable purposes. ${ }^{32}$

\footnotetext{
${ }^{26}$ Oppenheim v Tobacco Securities Trust Co Ltd [1951] AC 297, 305.

${ }^{27}$ See, eg, Dugalunji Aboriginal Corporation, The Rule Book of Dugalunji Aboriginal Corporation, 4 January 2013, 2; Lhere Artepe Aboriginal Corporation, Rule Book Lhere Artepe Aboriginal Corporation, 30 June 2014, 6.

${ }^{28}$ Re Gillespie (deceased) [1965] VR 402, 406.

${ }^{29}$ Pemsel [1891] AC 531, 583.

${ }^{30}$ Aboriginal Hostels Ltd v Darwin City Council (1985) 75 FLR 197; Flynn v Mamarika (1996) 130 FLR 218.

${ }^{31}$ For example, the United Kingdom's Charities Act 2011, c 25 and New Zealand's Charities Act 2005.

${ }^{32}$ See David Bradbury, Assistant Treasurer and Mark Butler, Minister for Social Cohesion, 'A Statutory Definition of Charity for Australia' (Joint Media Release, 28 June 2013); Matthew Harding, Ann O'Connell and Miranda Stewart, 'Defining Charity: A Literature Review' (University of Melbourne, Law School, 23 February 2011).
} 
The Australian federal government enacted the Charities Act (effective from 1 January 2014), which confirms the common law charitable purposes but also extends the range of charitable purposes. The additional areas include advancing culture, including promoting and fostering culture and preserving and protecting Australian heritage, and promoting reconciliation, mutual respect and tolerance between groups of individuals that are in Australia. ${ }^{33}$ It should be remembered, however, that this definition does not apply at the state level, and the result is that the common law concept of charity applies to any tax concessions that are granted in respect of charities and state taxes such as local government rates. ${ }^{34}$

\section{Special Federal Statutory Provisions for Charities that Receive Benefits in Respect of Native Title}

Although the courts have accepted that Indigenous Australians constitute a sufficient section of the public for charity law purposes, ${ }^{35}$ the requirement that a charity benefit a section of the public, unrelated by blood, poses a legal barrier for many PBCs wishing to establish a charity. ${ }^{36}$ This is because claims to native title and other traditional lands are often determined through kinship and descent from a common ancestor. ${ }^{37} \mathrm{~A}$ PBC that represents a group defined through kinship that wishes to establish a charity, would previously have failed the public benefit requirement, unless solely for the relief of poverty. ${ }^{38}$ This situation had been amended, to a limited extent, in the Charities Act.

Section 9 of the Charities Act has two parts. Subsection (1) states:

(1) This section applies to a purpose that an entity has if:

\footnotetext{
${ }^{33}$ Charities Act $\mathrm{s} 12(1)$.

${ }^{34}$ See generally Fiona Martin, 'Local Government Rates Exemptions for Indigenous Organisations: The Complexities of a State by State System' (2010) 14(1) Australian Indigenous Law Review 35.

${ }^{35}$ Aboriginal Hostels Ltd v Darwin City Council (1985) 75 FLR 197; Alice Springs Town Council v Mpweteyerre Aboriginal Corporation [1997] 139 FLR 236, 252.

${ }^{36}$ Alice Springs Town Council v Mpweteyerre Aboriginal Corporation [1997] 139 FLR 236, 252; Re Compton [1945] Ch 123; Oppenheim v Tobacco Securities Trust Co Ltd [1951] AC 297.

${ }^{37}$ Peter Sutton, Native Title in Australia: An Ethnographic Perspective (CUP, 2003); Peter Sutton, 'Aboriginal Country Groups and the Community of Native Title Holders' (National Native Title Tribunal Occasional Paper Series No 01, 2001); Jocelyn Grace, 'Claimant Group Descriptions: Beyond the Strictures of the Registration Test' (1999) 2(2) Land, Rights, Laws: Issues of Native Title 1, 1-2; Aboriginal Land Rights (Northern Territory) Act 1976 (Cth) s 3.

${ }^{38}$ Charities for the relief of poverty are an exception to the public benefit requirement where the ultimate impoverished beneficiaries are family members or employees, see Dingle $v$ Turner [1972] AC 601; Alice Springs Town Council v Mpweteyerre Aboriginal Corporation [1997] 139 FLR 236, 252.
} 
(a) the purpose is directed to the benefit of Indigenous individuals only; and

(b) the purpose is not for the public benefit under this Division (disregarding this section) only because of the relationships between the Indigenous individuals to whose benefit the purpose is directed.

In order for section 9 to apply there must therefore be an entity and that entity must have a purpose that is directed to the benefit of Indigenous individuals. It cannot have purposes that only include benefiting Indigenous people, amongst other purposes. Furthermore, the purpose must be 'directed to the benefit of', which seems to indicate very clear targeting of the ultimate beneficiaries of the charitable entity as Indigenous and individuals. Finally, the provision only applies if the entity would fail the public benefit test because of the relationship between the Indigenous individuals who are to be benefited.

Section 9(2) then provides that if the relevant entity receives, holds or manages an amount or benefit related to native title or other traditional rights of land ownership, and the purpose would not satisfy the public benefit because of the relationships between the Indigenous individuals, then the purpose is treated as being for the public benefit. Section 9 therefore overcomes the legal hurdle that PBCs with charitable purposes for the ultimate benefit of a group defined through kinship have faced in establishing charitable status. ${ }^{39}$ However, the exception to the general public benefit criterion is further restricted because the $\mathrm{PBC}$ must receive, hold or manage native title payments or benefits. Not all PBCs will be in this position.

\section{Advantages of Establishing a Prescribed Body Corporate as a Charity}

There are several reasons why PBCs, as representatives of native title groups, use a charity as a legal structure to receive mining payments and which the author has identified from the literature. ${ }^{40}$ Arguably the key reason is the exemption from income tax. In 2010, the joint submission to Treasury by the MCA and the NNTC stated:

\footnotetext{
${ }^{39}$ See Fiona Martin, 'Convergence and Divergence with the Common Law: The Public Benefit Test and Charities for Indigenous Peoples' in Matthew Harding, Ann O'Connell and Miranda Stewart (eds), Charity Law: An International Perspective (CUP, 2013) 159; Fiona Martin, 'The Income Tax Exempt Charitable Structure as a Vehicle for Holding Australian Native Title Interests: Some Lessons from New Zealand' in Marcia Langton and Judy Longbottom (eds), Community Futures, Legal Architecture: Foundations for Indigenous Peoples in the Global Mining Boom (Routledge, Oxford and New York, 2012) 195; Matthew Harding, Charity Law and the Liberal State (CUP, 2014). It should be noted that the public benefit test has always been applied less strictly where the charity was solely for the relief of poverty, see Dingle v Turner [1972] AC 601; Alice Springs Town Councilv Mpweteyerre Aboriginal Corporation [1997] 139 FLR 236, 252.

${ }^{40}$ Fiona Martin, 'The Legal Concept of Charity in the Context of Australian Taxation Law: The Public Benefit and Commercial Activities, Important Issues for Indigenous Charities' (2010) 25 Australian Tax Forum 275; Fiona Martin, Brad Morse and Barbara Hocking, 'The
} 
Currently, charitable trusts are commonly used for holding benefits from negotiated agreements to both maximise the value of the benefits and to avoid some of the difficult definitional issues that exist in current taxation arrangements. ${ }^{41}$

This exemption is important as many PBCs wish to maximise their income in order to make optimal use of their resources. In addition, mining companies often either do not wish to identify clearly in agreements what payments are in respect of, or consider that this would add to the complexity of the agreements, so they prefer the use of a charity to avoid some of the difficult definitional issues that exist regarding any income tax liability. ${ }^{42}$ Mining companies want clarity regarding any income tax liability arising from mining agreements, and the use of a charity as the recipient of the payments ensures clear parameters.

Until 2013 there was no statutory provision relating to the taxation or otherwise of payments relating to native title and the application of income tax principles was far from clear. ${ }^{43}$ The 2013 amendments to the ITAA97 now exclude from assessable and exempt income a narrow range of 'native title benefits'; ${ }^{44}$ however, they do not exempt the investment income from these monies. The only way that investment income earned by a PBC will be exempt from income tax is if the $\mathrm{PBC}$ is an income tax exempt entity such as a charity.

A further advantage of charitable status for PBCs is that once charitable, it must comply with its stated charitable purposes, and all activities must further these purposes. ${ }^{45}$ This is, however, subject to the proviso that non-charitable supporting or ancillary purposes will not cause the forfeiture of the entity's charitable status. ${ }^{46} \mathrm{~A}$ charity native title group can ensure that the use of native title benefits is limited to specified charitable purposes and not for private gain or uses that are outside these purposes. This limitation will go some way towards ensuring that native title benefits are not wasted by current native title groups and that they are used for community good. $^{47}$

\footnotetext{
Taxation Exemption of Canadian Indians as Governments and Individuals: How Does this Compare with Australia and New Zealand?' (2011) 40(2) Common Law World Review 119. ${ }^{41}$ MCA and NNTC, above n 3, 11.

${ }^{42}$ MCA and NNTC, above n 3,11; Fiona Martin, 'Native Title Payments and their Tax Consequences: Is the Federal Government's Recommendation of a Withholding Tax the Best Approach?' (2010) 33(3) University of New South Wales Law Journal 685.

${ }^{43}$ See Fiona Martin, Income Tax, Native Title and Mining Payments (Wolters/Kluwer, CCH, 2014); Martin, above n 42.

${ }^{44}$ ITAA97 s 59-50.

${ }^{45}$ Word Investments [2008] HCA 55 [17]; Stratton v Simpson (1970) 125 CLR 138, 159; Royal National Agricultural and Industrial Association v Chester [1974] 3 ALR 486, 489.

${ }^{46}$ Maclean Shire Council v Nungera Co-operative Society Ltd (1994) 84 LGERA 139.

${ }^{47}$ Victorian Native Title Legal Service, Submission to Australian Government, AttorneyGeneral, Discussion Paper: Leading Practice Agreements: Maximising Outcomes from Native Title Benefits, 2011, 1; Freehills Solicitors, Submission to Australian Government, Attorney-General, Discussion Paper: Leading Practice Agreements: Maximising Outcomes
} 
Establishing a PBC as a charity also means that the native title and any other property it owns is held on trust indefinitely. ${ }^{48}$ Charitable trusts, unlike trusts for human beneficiaries, can last for many generations. ${ }^{49}$ This advantage also applies to corporate entities; however, the articles of association of a company can be altered, whereas once an entity is a charity it must comply with its charitable purposes.

Intergenerational benefit is seen by many Indigenous cultures as a way of overcoming long-term disadvantage and ensuring continuity of cultural heritage. At the $14^{\text {th }}$ Annual Vincent Lingiari Lecture at Charles Darwin University, Sir Tipen O'Regan, a Māori elder, stated:

A considerable proportion of Māori collective capital is in Māori Incorporations and Trusts, in which shareholdings are privately held. Their purpose and governance is little different from the corporately owned assets in the wider economy. The only thing that is structurally distinctive about them is the Māoriness of their ownership $\cdots$

The difference lies in the intergenerational purpose for which they are owned and the intergenerational character of their ownership. What makes it different from individually owned Maori enterprise is that it has a shareholder who never dies. ${ }^{50}$

A further advantage from the mining industry perspective is that the use of charities demonstrates that the funds are 'doing a public good', which enhances their social responsibility and their reputation. ${ }^{51}$

\section{Challenges to Prescribed Bodies Corporate Gaining Charitable Status}

\section{A Ability to Carry On Business}

Even though the amendments to the legal definition of 'charity' have alleviated some of the pressures faced by PBCs that wish to gain charitable status, there are still certain challenges linked to this status that may be preventing them from accessing it. In many instances a charity will require some form of income to enable it to perform services or provide benefits such as scholarships, and which can also be

from Native Title Benefits, 2011, 1; Australians for Native Title and Reconciliation (ANTaR), Submission to Australian Government, Attorney-General, Discussion Paper:

Leading Practice Agreements: Maximising Outcomes from Native Title Benefits, November $2010,1$.

${ }^{48}$ Re Compton; Powell v Compton [1945] Ch 123, 126; Dal Pont, above n 1 [6.9].

${ }^{49}$ Re Tyler [1892] 3 Ch 252.

${ }^{50}$ Sir Tipen O'Regan, ' $14^{\text {th }}$ Annual Vincent Lingiari Lecture' (Speech delivered at Charles

Darwin University, ABC Radio National, October 2014).

${ }^{51} \mathrm{MCA}$ and NNTC, above n 3, 12. 
reinvested to obtain capital for future activities. ${ }^{52}$ Often this money is from government and philanthropic grants, although this is not always the case, because obtaining these grants is a highly competitive business and can be difficult. The public may also give donations and other support, but in these situations charities need to engage in fund-raising activities and not all are in the position to do this effectively. ${ }^{53}$ PBCs may gain income from mining, if they are in areas where this is occurring but they often wish to establish businesses to gain income, and for other reasons such as training and employment. Dugalunji Aboriginal Corporation is the PBC for an area of native title in northwest Queensland. ${ }^{54}$ It manages, protects and holds the native title $^{55}$ and has also carried on significant commercial enterprises since the early $2000 \mathrm{~s}$. One of its main enterprises is construction, which not only assists the local community by, for example, upgrading the road between Mt Isa and Camooweal where the community is located, but also providing apprenticeships and training to local Indigenous people. ${ }^{56}$ It is also a charity. ${ }^{57}$

Another example is the Lhere Artepe Aboriginal Corporation. This company is the PBC for an area of native title around Alice Springs. It owns, through a subsidiary corporation, the largest shopping centre in Alice Springs and several other commercial outlets. ${ }^{58}$ Lhere Artepe is also a charity.

The Gundjeihmi Aboriginal Corporation in the Northern Territory (although not a PBC), has carried on three small businesses for several years ${ }^{59}$ and in 2011 acquired a new business, the Two Rivers Newsagency and Post Office. ${ }^{60}$ These businesses were established not only to raise funds to carry on its charitable activities, but also to train unemployed Indigenous locals in skills that will assist them for future employment. ${ }^{61}$ As the 2010 Gundjeihmi Report states: 'In addition to their economic value, it is anticipated that the operation of these premises will be fully integrated

\footnotetext{
${ }^{52}$ Treasury, 'A Definition of Charity' (Consultation Paper, October 2011). Australian Government, Report of the Inquiry into the Definition of Charities and Related

Organisations (Ian Sheppard, Robert Fitzgerald and David Gonski, June 2001) 227-31.

${ }^{53}$ Ibid.

${ }^{54}$ Agreements, Treaties and Negotiated Settlements Project

$<$ http://www.atns.net.au/agreement.asp?Entity ID $=5537>$.

${ }^{55}$ The Rule Book of Dugalunji Aboriginal Corporation, 4 January 2013, 2.

${ }^{56}$ Paul Memmott, 'Demand-Responsive Services and Culturally Sustainable Enterprise in Remote Aboriginal Settings: A Case Study of the Myuma Group' (Aboriginal Environments Research Centre, The University of Queensland, 2009).

${ }^{57}$ ORIC, Financial Report (2014).

${ }^{58}$ Australian Government, Department of Finance and Deregulation, Office of Evaluation and Audit (Indigenous Programs), Performance Audit of Centrecorp Aboriginal Investment Corporation Pty Ltd (November 2008) 18; Lhere Artepe Aboriginal Corporation, Financial Report (2011).

${ }^{59}$ Gundjeihmi Aboriginal Corporation, Financial Report (2011) 20. These are Kakadu Tackle \& Boat Hire Store, It's Kakadu Store and Marrawuddi Gallery.

${ }^{60}$ Ibid 26.

${ }^{61}$ Gundjeihmi Aboriginal Corporation, The Mirarr: Yesterday, Today and Tomorrow - A Socioeconomic Update (2010) 24.
} 
with the youth development, training and employment programs run by the Corporation. ${ }^{, 62}$ The newsagency and post office is an example of a business that also provides an important service to a remote area and the art gallery enhances and promotes Indigenous culture. Businesses may therefore perform multiple roles for Indigenous communities.

Whether or not a charity can carry on a commercially operated business, and still retain its charitable status, has been a controversial issue for some time. In 2008, the High Court was required to deal with this issue in Federal Commissioner of Taxation $v$ Word Investments Ltd. ${ }^{63}$ Wycliffe Bible Translators (International) is a missionary organisation that seeks to spread the Christian religion through missionaries, and is particularly active in developing countries, and among sections of the population who have no written language. The missionaries learn the local language, teach people to read and write that language, translate the Bible into that language, and then teach the people how to read the Bible. One of its members is Wycliffe Bible Translators Australia ('Wycliffe'). Wycliffe was endorsed by the ATO from 1 July 2000 as a charity. Word Investments Ltd ('Word'), is a company limited by guarantee which was founded by members closely associated with Wycliffe who wanted to use Word to raise money within Australia, and give it to Wycliffe for the carrying out of its purposes. The memorandum of association of Word allowed it to carry on business activities in connection with its other purposes. These other purposes were accepted by the parties as charitable. Any funds from the business activities went directly to Wycliffe, and other related entities, to support the evangelical work, and therefore the religious charitable purpose. Word, however, engaged in the business activity of running a funeral business. The funeral business was conducted along commercial lines, and was open to the general public, not just members of the religion supported by Wycliffe and Word.

The crucial legal issue in the decision was whether a NFP could be considered charitable when it carried on a business, the funds from which went towards its purposes, which were all charitable. The majority in the High Court emphasised that Word's powers to carry on business activities were a means to it achieving its religious charitable purposes and therefore did not preclude charitable status. ${ }^{64}$ The Court stated:

Word endeavoured to make a profit, but only in aid of its charitable purposes. To point to the goal of profit and isolate it as the relevant purpose is to create a false dichotomy between characterisation of an institution as commercial and characterisation of it as charitable. ${ }^{65}$

\footnotetext{
${ }^{62}$ Ibid.

${ }^{63}$ [2008] HCA 55.

${ }^{64}$ Ibid [24].

${ }^{65}$ Ibid [24].
} 
The decision was viewed unfavourably by the Revenue and as a result, the ATO issued a Decision Impact Statement that confined the decision to its facts. ${ }^{66}$ In the 2011 federal budget, the Labor Government announced that there would be reforms to the charities and NFP sector to ensure that any income tax exemption did not apply to unrelated business income. ${ }^{67}$ In other words, income tax concessions would only apply to profits generated by unrelated commercial activities that were directed back to a charity to carry out its altruistic work. Charities would therefore pay income tax on profits from their unrelated commercial activities that were not directed back to their altruistic purpose (that is, the earnings they retained in their commercial undertaking). Commercial activities that furthered a charity's altruistic purposes, as well as small-scale and low-risk unrelated commercial activities, were excluded from these proposals.

In December 2013, the federal government (a coalition of the Liberal and National Country parties) stated that 'the Government will not proceed with the measure to "better target" not-for-profit tax concessions at this stage, but will explore simpler alternatives to address the risks to revenue'. ${ }^{68}$ One commentator has stated that 'the Coalition has indicated it is predisposed not to proceed with this measure'. ${ }^{69}$

Although at this stage there are no government plans for an amendment to charity law to tax income from unrelated businesses, clearly this is an area that is controversial. Controversy and uncertainty place charities for Indigenous Australians in a difficult situation where they wish to gain income and also maximise economic, social and cultural outcomes by carrying on businesses as discussed in the examples above. Business activities that they carry on, such as local construction businesses, shops and tourist facilities may, in many cases, be a significant aspect of the overall charitable purpose of improving the economic independence of a remote Indigenous community. There have, however, been instances of very profitable Indigenous businesses and/or those that compete with for-profit businesses in the same market, being subject to harsh criticism and potential loss of their charitable status. ${ }^{70}$

But the current situation is that PBCs that are charities are also able to carry on profitable businesses. These businesses may earn income for their community and may also provide other intangible benefits such as training and cultural enhancement. The benefits of being a charity are that the business income is exempt from income

\footnotetext{
${ }^{66}$ ATO, Decision Impact Statement, Commissioner of Taxation v Word Investments Ltd, 26 May 2009.

${ }^{67}$ Australian Government, Budget 2011-12, Not-for-profit sector reforms $<$ http://www.finance.gov. au/publications/ commonwealth-budget/2011-12/201112/content/bp2/html/bp2_revenue-07.htm>.

${ }^{68}$ Arthur Sinodinos, Assistant Treasurer, 'Integrity Restored to Australia's Tax System' (Media Release, 14 December 2013).

${ }^{69}$ Elizabeth Turnour, Moores, Solicitors, NFP Reform Agenda Update, 9 December 2013.

${ }^{70}$ For example, Australian Government, Department of Finance and Deregulation, Office of Evaluation and Audit (Indigenous Programs), Performance Audit of Centrecorp Aboriginal Investment Corporation Pty Ltd, November 2008, 18.
} 
tax, the charity must only work towards its charitable objectives and all surpluses must be reinvested into the charity.

\section{B Community Development}

'Community development' is a term that is often used in respect of Indigenous communities, although its actual meaning will vary depending on the circumstances and the context. Kenny defines community development as:

Processes, tasks, practices and visions for empowering communities to take collective responsibility for their own development. The aim of community development is to enable communities to have effective control of their own destinies. Effective control requires the development of ongoing structures and processes by which communities can identify their own issues, needs and problems within their own terms of reference. ${ }^{71}$

The Central Land Council in the Northern Territory, itself a charity, has established a community development unit. ${ }^{72}$ The unit's objectives include relief of poverty and disadvantage in the community as well as improvement in the health and education of its members, all of which are charitable. However, it also uses funds for infrastructure needs, recreational pursuits and sporting facilities. ${ }^{73}$ Unless otherwise attached to recognised charitable objects, providing entertainment and recreational facilities and the encouragement of sport are not charitable purposes, ${ }^{74}$ although they are important aspects of community development. ${ }^{75}$ In particular, sport is one area

\footnotetext{
${ }^{71}$ S Kenny, Developing Communities for the Future (Thompson, $3^{\text {rd }}$ ed, 2006) 10.

${ }^{72}$ Central Land Council, Annual Report (2009-2010) 82; Danielle Campbell and Janet Hunt, 'Community Development in Central Australia: Broadening the Benefits from Land Use Agreements' (Topical Issue 7, CAEPR, 2010) 2.

${ }^{73}$ Central Land Council, above n 72, 85.

${ }^{74}$ Building recreational halls and encouraging social activities by themselves are not charitable purposes; see Williams' Trustees v Inland Revenue Commissioners [1947] AC 447. Sport by itself is not a charitable purpose; see Strathalbyn Show Jumping Club Inc $v$ Mayes [2001] SASC 73 in Australia following Re Nottage; Jones v Palmer [1895] 2 Ch 649.

${ }^{75}$ Many Indigenous festivals are a significant aspect of the life of the community and an important contributor to health and wellbeing; see Peter Phipps and Lisa Slater, Indigenous Cultural Festivals: Evaluating Impact on Community Health and Wellbeing, Report to the Telstra Foundation 2007, 10. Many different sports have been adopted enthusiastically in Indigenous remote communities, eg AFL is an important part of cultural life on the Tiwi Islands; see Amos Aikman, 'For Tiwi's, Life's Goals Come from Sherrin', The Australian, 19 March 2012; AFL is regularly played in many remote communities; see ABC Radio AM, 'Indigenous Football Team to Play at the MCG', AM Program, 2009 (Tony Eastley) $<$ http://www.abc.net.au/am/content/2009/s2585257.htm>; since 2009 the NRL has organised an annual all-professional Indigenous game commonly referred to as the 'Indigenous All Stars' <http://www.nrl.com/indigenous-all-stars-v-nrl-allstarspreview/tabid/10976/newsid/65740/default.aspx>.
} 
where Indigenous and non-Indigenous people can interact on a level playing field, and in a positive way that enhances community development. ${ }^{76}$

There is therefore some doubt as to whether or not aspects of community development are charitable and can be legitimately carried on by a charity without jeopardising its charitable status. Concern about whether or not community development activities fall within charitable purposes has been stated in several submissions to the Australian government. For example, Native Title Services Victoria Ltd in its submission to both Treasury and the Attorney-General's Department regarding native title and economic development states that:

The charitable purposes test is not well understood and it is difficult to readily obtain guidance about the test. The uncertainty as to what activities do validly fall within the definition of charitable leads many groups to avoid certain activities, such as community development activities, which would have meaningful community benefits. $^{77}$

The joint submission of the University of Melbourne and AIATSIS to the federal government regarding native title and tax highlights the problem of charitable purpose not extending to Indigenous community development and commercial purposes. ${ }^{78}$ So do other submissions such as that of the MCA and the NNTC, ${ }^{79}$ the Law Council of Australia ${ }^{80}$ and Yamatji Marlpa Aboriginal Corporation. ${ }^{81}$

\section{Accumulation of Funds}

An important limitation for all charities is whether or not, and for how long, they can accumulate charitable funds. Any restrictions can impact severely on charity PBCs that wish to accumulate income for the benefit of future generations. ${ }^{82}$ The ATO stated in a 2011 Taxation Ruling that a charitable entity can accumulate income as long as this accumulation is in order to increase the funds available to the organisation

\footnotetext{
${ }^{76}$ Emma E Campbell and Christopher C Sonn, 'Transitioning into the AFL: Indigenous Football Players' Perspectives' (2009) 11(3) Athletic Insight: The Online Journal of Sport Psychology.

${ }^{77}$ Submission to Treasury, Native Title, Indigenous Economic Development and Tax: Consultation Paper, 30 November 2010, 4; Submission to Attorney-General Department, Leading Practice Agreements: Maximising Outcomes from Native Title Benefits, 30 November 2010, 4.

${ }^{78}$ Agreements, Treaties and Negotiated Settlements Project, Melbourne University and AIATSIS, Joint Submission to Treasury, Native Title, Indigenous Economic Development and Tax: Consultation Paper, 2010, 13.

${ }^{79} \mathrm{MCA}$ and NNTC, above $\mathrm{n} 3$.

${ }^{80}$ Law Council of Australia, Submission to Treasury, Native Title, Indigenous Economic Development and Tax: Consultation Paper, 30 November 2010.

${ }^{81}$ Yamatji Marlpa Aboriginal Corporation, Submission to Treasury, Native Title, Indigenous Economic Development and Tax: Consultation Paper, November 2010.

${ }^{82}$ Ian Murray, 'Charity Accumulation: Interrogating the Conventional View on Tax Restraints’ (2015) 37 Sydney Law Review 541, 543.
} 
and for the organisation to carry out its charitable purpose. ${ }^{83}$ A subsequent 2015 ruling clarified the ATO position and reiterated this point, but also provided in respect of accumulation that ' $[\mathrm{t}] \mathrm{o}$ satisfy the income and assets condition, an entity that accumulates most of its income over a number of years will need to show on a year by year basis that the accumulation is consistent with the purpose for which the entity is established'. ${ }^{84}$ A later paragraph in the ruling states that the 'income received by an entity must be put to use within a reasonable period of receipt' ${ }^{85}$

In 2012 the High Court accepted the ATO's submission that funds of a charity must be used for the charitable purposes of the entity, and that accumulation can only occur if this is in order to further those purposes. ${ }^{86}$ In coming to this conclusion the High Court specifically rejected the taxpayers' argument that it was acceptable that the funds were 'substantially' used for the entity's charitable purposes. ${ }^{87}$ It is arguable that this decision supports the ATO view that it has very broad powers over a charity's ability to accumulate. ${ }^{88}$

The power to restrict accumulation of funds by charities is a significant limitation for Indigenous charities in receipt of mining payments. This is due to the fact that, in many cases, mines will last for over 10 years and therefore the charities will wish to ensure that some of the mining funds provide long-term benefits. There are many instances, however, of the ATO restricting the ability to accumulate funds of charities to a maximum of 10 years. ${ }^{89}$ As the MCA and NNTC stated:

Disappointingly, the ATO may seek to limit tax concession charity status to a relatively short accumulation period (eg 10 years), requiring a subsequent review by the ATO to extend the Tax Concession Charities (TCC) status of the trust. This hinders the ability of Traditional Owners to provide for future generations. This is particularly important in the native title context where agreements affect intergenerational rights. It is also significant where agreements are in respect of mining and the life of the mine is commonly 20-30 years. In such cases it is important for the Traditional Owners to accumulate funds for a significant period of

\footnotetext{
${ }^{83}$ ATO, above n 20 [39].

${ }^{84}$ ATO, Income Tax: Special Conditions for Various Entities Whose Ordinary and Statutory Income is Exempt, TR 2015/1, 25 February 2015 [32].

${ }^{85}$ Ibid [160].

${ }^{86}$ Commissioner of Taxation v Bargwanna [2012] HCA 11 [31], [44].

${ }^{87}$ Ibid [44].

${ }^{88}$ Matthew Turnour and Myles McGregor-Lowndes, 'Taxing Charities: Reform Without Reason?' (2012) Taxation in Australia 74, 75.

${ }^{89}$ See MCA and NNTC, Joint Submission to Treasury, A Definition of Charity: Consultation Paper, 14 December 2011, 4-8; Adam Levin, 'Improvements to the Tax and Legal Environment for Aboriginal Community Organisations and Trusts' (Paper presented at the Agreements, Treaties and Negotiated Settlements Workshop, 28 August 2007, AIATSIS and at the Indigenous Communities, Economic Development and Tax Policy Symposium, University of Melbourne, 26-27 February 2008).
} 
the mine's life so that the funds can be appropriately managed, taking into account the current needs and intergenerational requirements. ${ }^{90}$

\section{The Current Charitable Status of Prescribed Bodies Corporate}

The ACNC reported that, as of December 2013, only 23 out of 118 PBCs are actually registered as charities with the ACNC. ${ }^{91}$ This means that 95 PBCs are not charities.

The breakdown of these 95 PBCs in terms of financial and geographical situation is as follows: ${ }^{92}$

\begin{tabular}{|l|l|l|l|l|l|}
\hline State/Territory & $\begin{array}{l}\text { Small (no } \\
\text { assets/income) }\end{array}$ & $\begin{array}{l}\text { Small (some } \\
\text { assets/income/staff) }\end{array}$ & Medium & Large & Total \\
\hline NSW & 2 & 0 & 1 & 0 & 3 \\
\hline NT & $12^{93}$ & 2 & 0 & 0 & 14 \\
\hline Qld & 17 & 10 & 2 & 0 & 29 \\
\hline $\begin{array}{l}\text { Qld (Torres Strait } \\
\text { slands) }\end{array}$ & 16 & 2 & 1 & 0 & 19 \\
\hline SA & 3 & 3 & 4 & 0 & 10 \\
\hline Vic & 0 & 1 & 4 & 0 & 2 \\
\hline WA & 9 & 6 & 1 & 1 & 18 \\
\hline Totals & 59 & 24 & 2 & 11 & 95 \\
\hline
\end{tabular}

The information above demonstrates that Queensland has by far the largest number of PBCs at 48, with Western Australia second at 18.

The ACNC groups charities into small, medium and large for the purposes of charities lodging annual information statements and financial reports. ${ }^{94} \mathrm{~A}$ small registered charity is one with annual revenue under $\$ 250,000$; a medium charity is one with annual revenue between $\$ 250,000$ and $\$ 1,000,000$, and a large charity one with revenue of $\$ 1,000,000$ or more. ${ }^{95}$ Revenue includes government and other grants, donations (tithing), bequests or legacies, sales of goods or inflows from other fundraising activities, fees and charges for provision of services, interest earned and dividends or similar distributions. ${ }^{96}$

The above table demonstrates that there are 59 small PBCs with no assets or income. These entities may not find it useful to register as charities as any exemption from

\footnotetext{
${ }^{90}$ MCA and NNTC, above n 89, 4.

${ }^{91}$ Keely, Lovett and Patterson, above $n 9$.

${ }^{92}$ Ibid 9.

${ }^{93}$ Includes one not registered with the Office of the Registrar of Indigenous Corporations.

${ }^{94}$ Australian Charities and Not-for-Profits Commission Act 2012 (Cth) s 60-1.

${ }^{95}$ Ibid s 205-25.

${ }^{96}$ ACNC, Factsheet: Charity Size and Revenue <http://www.acnc.gov.au/ACNC/Pblctns /Factsheets/ACNC/FTS/ Fact_CharSize.aspx $>$.
} 
income tax would be minimal. ${ }^{97}$ Furthermore, there are compliance issues associated with registration as a charity, even a small one, such as preparing registration documents and lodging annual information statements with the ACNC, and these costs would probably outweigh any benefits.

Charitable status will, however, be potentially important to the 11 medium and one large PBC. Charitable status may benefit these entities in several ways. First, any income they derive from commercial activities or investments will be exempt from income tax. Their employees may also be able to benefit from salary packaging of benefits. As charities they would be rebatable employers under the Fringe Benefits Tax Assessment Act 1986 (Cth). By offering salary packaging, they can increase the employees' take home salaries at no actual cost to the charities, ${ }^{98}$ potentially attracting better qualified and more experienced employees without paying higher salaries.

The second group of 24 small charities have low income, but they do have assets and also employees. These entities have some revenue and may, depending on its source and whether or not they generate any surplus after expenses, gain benefit from the exemption from income tax. They also have employees and, if they became charities, could also access certain fringe benefit concessions.

Another significant advantage of charitable status is the ability of charities to access government and philanthropic grants. Many granting bodies will only award grants to registered charities. For example, under the grants programs of the Sidney Myer Foundation and the Vincent Fairfax Family Foundation, grants are only made to registered charities. ${ }^{99}$ This aspect of charitable status may be attractive to these PBCs and should be considered by their boards of management.

A further significant consideration, and potential advantage for PBCs establishing charities, is that the entities' purposes must all be charitable purposes. At common law, these charitable purposes were established by the case law, as articulated in the four heads in Pemsel. The Charities Act has broadened the scope of charitable purposes to include such areas as 'promoting reconciliation, mutual respect and tolerance between groups of individuals that are in Australia' and the purpose of 'advancing culture'. ${ }^{100}$ Political activity aimed at changing the law or government policy is also a charitable purpose, as long as it is in furtherance of one of the charitable purposes set out in section 12(1)(a)-(k) of the Charities Act. PBCs, as

\footnotetext{
${ }^{97}$ Keely, Lovett and Patterson, above n 9, 9.

${ }^{98}$ Generally, eligible employers direct their employees to 'salary packaging' providers so that they do not incur any costs of advice and restructuring of the salary and benefits, See EPAC Salary Packaging <https://www.epac salarysolutions.com /Public/SalaryPackagingCalculator/Calculator.aspx?mode=Rebatable>; Salary Packaging Cards $<$ http://www.salary packagingcards.com.au/index.php/fbt-rebatable-employers/>.

${ }^{99}$ Sidney Myer Small Grants Program <http://myerfoundation.org.au/grants/povertydisadvantage/small-grants/>; Vincent Fairfax Family Foundation $<\mathrm{http}$ //community.grantready.com.au/Find_Grants/Search/index .aspx?itemDetails=3880>. ${ }^{100}$ See Charities Act s 12(1)(e)-(f).
} 
representatives of their native title group, may find it appropriate to have their organisation's purposes limited to areas that are for the benefit of the entire community. As native title is a communal asset, charitable aims (which by their very nature are intended to benefit a section of the public, rather than an individual) fit more easily with the ethos underpinning native title. PBCs that also register as charities can aim to benefit not only the current native title group, but also future generations.

A final important consideration is that the assets of a charity must be used for the entity's charitable purposes and, on a winding up of the charity, transferred to another charity with similar charitable aims. This longevity of the charitable purposes of the organisation may be attractive to a PBC, as this would fit with the tenet of the native title holder maintaining and protecting native title for future generations.

\section{Conclusion}

Charitable status can provide many significant benefits for PBCs. The most obvious is the exemption from income tax, not only of any income received by a charity, but of the income arising from any of its investments or businesses. Although the 2013 amendments to the ITAA97 exempt from income tax certain payments in respect of native title, which means that some mining payments paid to PBCs are not subject to income tax, the range of payments is relatively narrow and the exemption does not extend to investment and business income derived by the PBC.

Although at times seen as controversial, charities are legally able to carry on profitable businesses. These businesses may earn income for the PBC's community and may also provide other intangible benefits such as training and cultural enhancement. The benefits of being a charity are that the business income is exempt from income tax, the charity must only work towards its charitable objectives, and all surpluses must be reinvested into the charity.

A further benefit of charitable status is that the entity and its objectives can exist in perpetuity, thus being able to continue to benefit future generations. This gives them the potential to provide intergenerational benefits. Indigenous Australians, especially in the areas of native title and traditional land ownership, view provision for future generations as integral to the continuity of Indigenous land ownership and culture. ${ }^{101}$ The fact that PBCs may wish to use their income for community development purposes and such purposes often coincide with charitable purposes is also an advantage. This links to the additional advantage that charities are NFP, so that any surpluses of income over expenses are reinvested into the entity. In this way the entire

\footnotetext{
${ }^{101}$ Marcia Langton and Angus Frith, 'Legal Personality and Native Title Corporations: The Problem of Perpetual Succession' in Lisa Strelein (ed), Dialogue About Land Justice (Aboriginal Studies Press, 2010) 173, 181.
} 
funds received by the charity are used for the benefit of, and reinvested into, the relevant community.

There are, however, some drawbacks to the establishment of charities. Of most significance is the difficulty of obtaining charitable status for community development or sporting purposes unless they coincide with a charitable purpose. Both these areas are of particular relevance and importance to native title groups.

A final drawback, depending on the circumstances of the PBC, is the limitation on accumulation of funds by charities. This is of particular significance in the context of mining payments because mines often last far in excess of 10 years. A prudent native title group will wish to accumulate capital from mining payments in order to build up funds from which income is derived and which can support its philanthropic endeavours. Where a mine is estimated to be in existence for a lengthy period of time, the investment phase for the majority of mining payments may last the length of the mine. This may not be possible if the ATO enforces its 10 -year accumulation policy strictly. 